\title{
The Effect of Strategy-Based Instruction on Students' Speaking Skills atLakidende University
}

\author{
Irawati \\ Haryanto \\ Syarifuddin Dollah \\ State University of Makasar, Indonesia
}

\begin{abstract}
:
This study aimed at investigating the effect of strategies-based instruction on students' speaking skill at Lakidende University and the students' interest in learning English through strategies-based instruction. This research employed Quasi Experimental Method, with non-equivalent control group design. This research assigned experimental group and control group (30 students for each).Speaking test was used to see the effect of strategies-based instruction on students' speaking skill and questionnaire was used to see students' interest in learning English through strategies-based instruction. The data obtained through the speaking test were analyzed by using descriptive statistics and inferential statistics. Meanwhile, the data from questionnaire were analyzed in percentage and descriptive statistics. The students' speaking skill covered three components: accuracy, fluency, and comprehensibility. The findings showed that there was an improvement on the students' speaking ability after the treatment. There was a significant difference between the results of post-test of experimental and control group, where the mean score of post-test of experimental group was 70.37, which was higher than the mean score of posttest of control group was 59.63. The value of P-value or sig. (2-tailed) shows that $\mathrm{P}$-value or sig. (2-tailed) is smaller than $\alpha(0.00<0.05)$.Furthermore, the data that were collected from questionnaire showed that the students were very high interest toward strategies-based instruction. It is showed by the mean score in scale of 89.6 , which was categorized as very high interest.
\end{abstract}

Keywords: effect, strategy-based instruction, speaking skill

\section{INTRODUCTION}

Speaking is one of courses taught to the students of English major at Lakidende University. As a productive skill, speaking is an important component in language learning. In general, students in Lakidende 


\section{$92 \mid$ ELT Worldwide Vol. 1 No. 1}

University are expected to develop their speaking skills through speaking activities that are conducted by lecturers. The speaking activities are designed on the basis of the Speaking Course outline in Lakidende University.

The speaking skills have applied various techniques that are assumed to support students to develop their speaking skills. In fact, some students were often particularly reticent in speaking. It was found, through unstructured interview with some students, that they are reticent in speaking because they feel shy, lack vocabulary, and are worried about making mistakes. It is also assumed that another reason behind students' being reticent in speaking is, they lack usable strategies while speaking in order to complete a speaking task. As a result, students lack interest in participating in speaking activities in classrooms. Meanwhile, speaking English fluently and accurately and communicating verbally in target language is always a grand task for foreign language learners since effective verbal communication requires the ability to use the language appropriately in social interactions (Atik, 2006, p 3).

Concerning the problems faced by students in Lakidende University, the researcher got interested in teaching the students with learning strategies related to speaking skills. Underlying every learning task is at least one strategy (Nunan, 1999). In speaking most of the students are unaware of the strategies underlying the learning tasks in which they are engaged. According to Nunan (1999, p 171), knowledge of strategies is important because it gives one a greater awareness of what one is doing. If one is conscious of the processes underlying the learning that one is involved in, learning will be more effective.

The strategies used to improve students' speaking skill were metacognitive strategies, cognitive strategies, affective strategies and social strategies proposed by Oxford (1990) and Cohen et al. (1995). There are numerous means of providing strategy instruction for learners. One way to train students is by strategy-based instruction. Teaching strategies in speaking using strategies-based instruction will make learners become autonomous in their search for knowledge and for taking responsibility of their own learning (Atik, 2006, p 2). Strategies-based instruction has been referred to as 'strategy training' or 'strategy instruction' or 'learner training' (Chamot\& Rubin, 1994, p 771 in Cohen et al, 1995, p 5). Strategies-based instruction offers a foreign language teacher a way to integrate language learning strategies directly into the foreign language classroom.

The researcher assumed that integrating learning strategies into the language tasks with various techniques in teaching speaking in classroom could improve students' speaking skill. Given this background, the purpose of this research was to investigate whether or not strategies-based instruction has a 
Irawati, AtmowardoyoEDDollah, The Effect of Strategies-Based Instruction $\mid 93$

significant effect on students' speaking skills at Lakidende University, and to investigate whether or not students at Lakidende University are interested in learning English through strategies-based instruction.

\section{LITERATURE REVIEW}

Strategies-based instruction has a number of possible manifestations in the classroom (Brown, 2000, p 135). Strategies-based Instruction is the application of both learning and communication strategies to classroom learning (Cohen, 1998 in Brown 2000, p 130). Cohen states that the underlying premise of the strategies-based instruction is that studentsshould be given the opportunity to understand not only what they can learn in the language classroom, but also how they can learn the language more effectively and efficiently. Research seems to suggest that there is a wide variety of strategies that learners can use to meet their language learning and using needs (online). In strategies-based instruction, teachers may start with the established course materials and then insert strategies, or start with a set of strategies and design activities around them or insert strategies spontaneously into the lessons when appropriate (Cohen et al, 1995,p. 7)

Oxford, Crookall, Cohen, Lavine, Nykos, \& Sutter (1990 in Cohen, 1995,p.132) outline a sequence for the introduction of strategies that emphasize explicit strategy awareness, discussion of the benefits of strategy use, functional and contextualized practice with the strategies, selfevaluation and monitoring of language performance, and suggestions for or demonstrations of the transferability of the strategies to new language tasks. The steps are (1) Language Activity: ask learners to do a language activity without any strategy instruction; (2) Discussion of Strategy Use: have them discuss how they did it, praise any useful strategies and self-directed attitudes that they mention, and ask them to reflect on how the strategies they selected may have facilitated the learning process; (3) Suggestions for Complementing Strategy Repertoire: suggest and demonstrate other helpful strategies, mentioning the need for greater self-direction and expected benefits, and making sure that the students are aware of the rationale for strategy use.Learners can also be asked to identify those strategies that they do not currently use, and consider ways that they could include new strategies in their learning repertoires; (4) Strategy Practice: allow learners plenty of time to practice the new strategies with language tasks; (5) Strategy Transfer: show how the strategies can be transferred to other tasks; (6) Strategy Practice with New Tasks: provide practice using the techniques with new tasks and allow learners to make choices about the strategy they will use to complete the language learning task;and (7) Evaluating Strategy Use: help students understand how to evaluate the success of their strategy use and to gauge their progress as more responsible and self-directed learners. 
94| ELT Worldwide Vol. 1 No. 1

Strategies-based instruction activities are designed to raise awareness about strategies, to train students in strategy use, to give them opportunities to practice strategy usage and to encourage them to personalize these strategies for themselves. Teachers also allow students to choose their own strategies and do so spontaneously, without continued prompting from the language teacher (Cohen et al, 2005).

\section{METHOD}

\section{Design and Samples}

This research applied quasi-experimental design along with non-equivalent control group design. It is employed when it is not possible to randomly assign individual participants to groups (Gay et al. 2006, p.257). In this research, the groups were assigned randomly in an experimental group and a control group. The sample in the experimental group consisted of 30 students (Group/Class B) and the control group consisted of 30 students (Group/Class C). They were freshmen who took the Speaking course. The experimental group received treatment by using strategies-based instruction. The treatment in experimental group consisted of five stages of strategiesbased instruction: preparation, presentation, practice, evaluation and expansion (stages proposed by Chamot,2005). Meanwhile the control group did not receive any treatment of strategies-based instruction. The stages in the control group consisted of pre-activity, activity and post-activity. In other words, the control group was taught by using non-strategies-based instruction. However, both groups received the same speaking materials and speaking activities.

\section{Instruments and Procedure}

The present research was aimed at investigating the effect of strategies-based instruction on students' speaking skills at Lakidende University and to investigate students' interest in learning English through strategies-based instruction. To see the effect of strategies-based instruction, the researcher conducted a speaking test in a pre-test and post-test. The speaking test consisted of three questions and was given in the form of verbal interview. A pre-test and post-test were given to both groups - the experimental and the control group. Giving a pre-test was aimed at seeing students' achievement in speaking before treatment by strategies-based instruction, while giving a post-test was aimed at measuring students' achievement in speaking after treatment by strategies-based instruction. In conducting the pre-test and posttests to both groups, the researcher administered specific steps. These were as follows: a) interviewing students one by one: during the interview, the researcher recorded the students' responses to find more accurate data; $b$ ) giving scores to students' speaking skills by listening and transcribing the 
recordings. In assessing the students' speaking skills, three aspects of speaking were covered: fluency, accuracy and comprehensibility. The students' speaking skills scoring was based on the scoring classification proposed by Heaton (1988, p 100). Meanwhile, a questionnaire was distributed to students in the experimental group to measure their interest in learning English through strategy-based instruction.

The treatments in experimental group were conducted for six meetings. After administering the pre-test, the researcher conducted a review of learning strategies that had been applied by the students in learning speaking skills. It was done in the first meeting. As part of strategy-based instruction, it was aimed at investigating students' speaking strategy usage before teaching through strategy-based instruction, helping students gain awareness of new strategies they can use in language learning, and letting students identify others who have tried similar and different strategies.

In the remaining five meetings, treatments through strategies-based instruction were carried out in the experimental group. The control group was taught without strategies-based instruction. But both groups were taught with the same material based on Speaking II syllabus in Lakidende University. Each meeting ran for 90 minutes.

During treatments, the researcher explicitly prompted the students to use their learning strategies in completing their speaking task given by the researcher. In the second meeting, the speaking instruction focused on describing pictures in which the activities were aimed at finding differences.In the third and fourth meetings, the speaking focused on sequencing pictures by rearranging them to construct a story based on sequenced pictures. In the fifth and the sixth meetings, the focus was on role play.

In teaching speaking through strategy-based instruction, the researcher applied the following steps (Chamot, 2005):

1. Preparation: In this stage, the students were told the purpose and importance of strategy use in speaking. Then the researcher activated the students' background knowledge of the strategies they had already been using to help them complete a specific task.

2. Presentation: In this stage, the researcher taught the material or the new concept or language skill, along with one or two strategies. The researcher previewed the strategies that were introduced in the first meeting. The researcher reminded the students verbally about the strategies they could use while completing a speaking task.

3. Practice: In this stage, the content and language skills the researcher taught served as the materials for students to practice the strategy. The 
96| ELT Worldwide Vol. 1 No. 1

researcher asked the students to prepare their strategy usage before, during and after completing a speaking task (Cohen, et al. 1995,p.114).

4. Evaluation: This stage focused on the students' self-evaluation - their discovering of the learning strategies that worked best for them on certain tasks. In this way, they could refine their individual repertoire of strategies. The students wrote their self-evaluation in their diaries.

5. Expansion: This stage was designed to develop students' transfer of strategies to new tasks. The researcher encouraged the students to apply the strategies they had learned to another speaking task or in suitable opportunities for speaking English. To support this stage, the researcher gave an assignment to students.

\section{Data Analysis}

To examine the effects of strategies-based instruction on students' speaking skills, two major statistical procedures were applied: (1) descriptive statistics, including means and standard deviations; and (2) inferential statistics, a paired-sample t-test that was carried out to compare students' achievement in speaking before and after the strategy instruction. The data from the questionnaire were analyzed into percentages to find the students' interest toward strategies-based instruction in the teaching-learning process. Subsequently, the mean score was calculated. In this case, the students' interest was categorized into positive and negative statements. After that, the result of the mean score was interpreted into five categories as showed in Table 1.

Table 1. Rating of the Interval Score of Students' Interest

\begin{tabular}{|l|c|}
\hline \multicolumn{1}{|c|}{ Range } & Category \\
\hline $85-100$ & Very high \\
\hline $69-84$ & High \\
\hline $53-68$ & Moderate \\
\hline $37-52$ & Low \\
\hline $20-36$ & Very low \\
\hline
\end{tabular}

(Sugiyono, 2008, p 182)

\section{RESULTS AND DISCUSSIONS}

\section{Students' Speaking Achievement}

The distribution of the score of the students' speaking achievement for the experimental and control groups in post-test shows a difference from the pretest. After conducting the treatment, both groups showed an improvement, but in the experimental group, improvement was higher than that of the control group. 
The mean score and standard deviation of the students' speaking achievement in pre-test and post-test for the experimental group are shown in Table 2.

Table 2. Mean Score and Standard Deviation of Students'Speaking Achievement in Pre-test and Post-test

\begin{tabular}{|c|c|c|c|}
\hline \multicolumn{2}{|c|}{ Group } & Mean & Standard deviation \\
\hline \multirow{2}{*}{ Pretest } & Experimental group & 51.66 & 14.89 \\
\cline { 2 - 4 } & Control group & 50.36 & 15.15 \\
\hline \multirow{2}{*}{ Post-test } & Experimental group & 70.37 & 10.45 \\
\cline { 2 - 4 } & Control group & 59.63 & 12.02 \\
\hline
\end{tabular}

Table 2 shows the difference of mean score and standard deviation in the pre-tests and post-tests of both groups. The result of data analyses shows that the mean score of the experimental group and the control group was almost the same score before giving the treatment. After conducting the treatment, the scores of the post-test of the experimental and the control group show different mean score. It implies that there was an improvement after conducting the treatment. Table 2 shows that the mean score of the students' pre-test of the experimental group was 51.66 and the standard deviation was 14.89 , while in the control group, the mean score of the students' pre-test was 50.36 and the standard deviation was 15.15 . The mean score of the posttest in the experimental group after the treatment was 70.37 with standard deviation of 10.45, and the mean score of the post-test in the control group was 59.63 while the standard deviation was 12.02 . It shows that the mean score of the experimental group was higher than the control group (70.37>59.63).

The results of the students' improvement in the experimental and control groupsare shown in Figure 1.

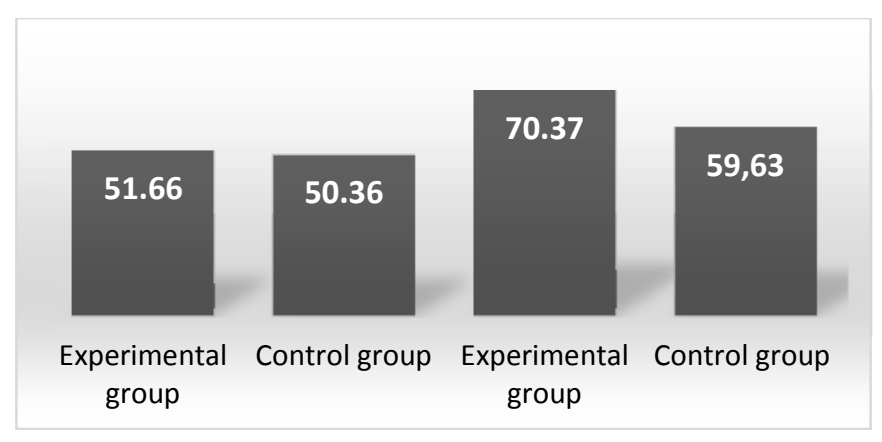

The researcher used a t-test or paired samples test for an independent sample test, that is, a test to know the significance of difference between the result of students' mean scores in all mean score of pre-tests and post-tests. 
98| ELT Worldwide Vol. 1 No. 1

Assuming that the level of significance $(\alpha)=0.05$, the only thing which is needed; the degree of freedom $(\mathrm{df})=\mathrm{N}-2=58$. Below are the t-test results in pre-test and post-test of the experimental and the control group in terms of accuracy, fluency, and comprehensibility.

Table 3. The Probability Value of T-Test of the Experimental and the Control Group Achievement

\begin{tabular}{|c|c|c|c|c|}
\hline Experimental Group & $\mathbf{t}$ & 2 Tailed Value & $(\boldsymbol{\alpha})$ & Remarks \\
\hline Pre-test and Post-test & 11.624 & 0.00 & 0.05 & Significantly Different \\
\hline Control Group & $\mathrm{t}$ & 2 Tailed Value & $(\boldsymbol{\alpha})$ & Remarks \\
\hline Pre-test and Post-test & 9.897 & 0.00 & 0.05 & Significantly Different \\
\hline
\end{tabular}

Table 3 shows the probability value of the t-test of the experimental and control groups' achievement. In the experimental group, the result of data analysis shows that there were significant difference between pre-test and post-test results, where the probability value $(0.00)$ is smaller than the level of significance at t-table (0.05). It can be inferred that the probability value was smaller than $\alpha(0.00<0.05)$. In the control group the result of analysis of pre-test and post-test also shows that there was significant difference between pre-test and post-test result. The result of data analysis shows that the probability value (0.00) is smaller than the level of significance at t-table $(0.05)$ or it can be said that the probability value was smaller than $\alpha$ $(0.00<0.05)$.

Table 4. The Probability Value of t-test of the Experimental and the Control Group Achievement in Pre-test and Post-test

\begin{tabular}{|c|c|c|c|c|}
\hline & $\mathbf{t}$ & $\begin{array}{c}\text { 2 Tailed } \\
\text { Value }\end{array}$ & $(\boldsymbol{\alpha})$ & Remarks \\
\hline $\begin{array}{c}\text { Experimental and Control Group } \\
\text { Pre-test }\end{array}$ & 0.33 & 0.74 & 0.05 & No Different \\
\hline $\begin{array}{c}\text { Experimental and Control Group } \\
\text { Post-test }\end{array}$ & 3.74 & 0.00 & 0.05 & $\begin{array}{c}\text { Significantly } \\
\text { Different }\end{array}$ \\
\hline
\end{tabular}

The result of data analyses in Table 4 shows that the t-tailed value is higher than probability value with $\alpha(0.05)$. It shows that there was no difference between pre-test in the experimental and control groups. In the other words, there was no significant difference between the students speaking ability in both groups before treatment. Since the result of the data analysis on posttest of the control and the experimental groups shows that the t-tailed value was smaller than $\alpha(0.00<0.05)$,meaning that the application of strategybased instruction definitely improve students' speaking skills. 
Irawati, Atmowardoyo\&Dollah, The Effect of Strategies-Based Instruction |99

The researcher concludes that the data of post-test as the final result displays significant improvement. It can be summarized that the use of strategiesbased instruction was able to provide a greater contribution in teaching speaking. In the other words, the use of strategies-based instruction in teaching speaking was effective.

\section{Students' Interest}

Questionnaires were distributed to the students to learn their level of interest toward strategy-based instruction. The students' interval score indicates that, regarding the use of strategies-based instruction in teaching speaking, 21 students felt strongly positive, categorized as very high interest (70 percent), 9 students felt positive, categorized as high interest (30 percent), and none of the students felt neutral, negative or strongly negative. Then, through descriptive statistics analysis, it was found that the mean score of students' interest was 89.63 with standard deviation 5.94 which proves very high interest.

During the teaching and learning process, students paid serious attention, participated well in speaking class activities, asked their lecturer in case of need and cooperated with their peers. Given the findings and discussions above, it can said that the use of strategy-based instruction improved the students' speaking skills and made them interested in learning English, especially speaking skills. In the researcher's mind, there are some reasons why the use of strategies-based instruction can improve the students' speaking skills because in strategy-based instruction speaking strategies were taught to students. This is supported by Nunan (1999, p 171) who states that knowledge of strategies is important, because the greater awareness you have of what you are doing, if you are conscious of the processes underlying the learning that you are involved in, then the learning will be more effective.

\section{CONCLUSION AND SUGGESTIONS}

The use of strategy-based instruction in teaching speaking hada significant impact on the students' speaking skills in Lakidende University. It can be seen from the students' mean score of post-test which was 70.37 for the experimental group, and 59.63 for the control group, and from the fact that the t-test of the students' speaking achievement in the experimental and the control group in post-test was smaller than $\alpha(0.00<0.05)$. The students also showed interested in learning English speaking through strategies-based instruction. The mean score of students' interest was 89.63 , which can be classified as very high interest.

Some limitations have also occurred in this research. First, this research focused on students' speaking achievement only. There was no investigation 
about students' speaking strategy use after treatment. Second, this research conducted during a short period of instruction, only a half semester or 5 meetings. The researcher assumed that strategy-based instruction needed to be conducted for a long time, for example, for a semester period or a year. By applying strategy-based instruction over a long period of time, students can be guided intensively to become autonomous learner.

Based on the conclusions and limitations above, the researcher puts forward some suggestions. It is suggested that the teaching of speaking through strategy-based instruction should be continually implemented in the English Education Study Program of Lakidende University. The researcher also suggest further research to investigate students' speaking strategy use after treatment or each speaking task, assuming that different speaking taskstrigger different strategy use. It is suggested that research about strategy-based instruction be conducted over aone semester period or a year. The researcher also recommends to future researchersthat they conduct research by applying strategy-based instruction in the teaching of other skills such as reading, listening and writing skills.

\section{REFERENCES}

Atik, B. B. (2006). Theeffect of strategies-based instruction on speaking skills of high school students. Adana: Cukurova University.

Brown, D.H. (2000).Principles of language learning and teaching. New York: Addison Wesley Longman, Inc.

Chamot, A. U. (2005). Language learning strategy instruction: Current issues and research. Annual Review of Applied Linguistics, 25, 112-130.

Cohen, A.D., Weaver, S. J.\& Li, T-Y. (1995). Theimpact of strategies-Based Instruction on speaking a foreign language. Washington: National Language Resource Center.

Gay, L. R., Mills, G. E. \&Airasian, P.(2006). Educational research.New Jersey: Pearson Prentice Hall.

Heaton, J. B. (1988). Writing English language tests. Longman, Inc.

Nunan, D.(1999). Second language teaching and learning. Boston: Heinle\&Heinle Publisher.

Oxford, R. (1990). Language learning strategies: Whatever teacher should know. New York: Newbury House Publisher.

Sugiyono. (2008). Metode penelitian pendidikan, pendekatan kuantitatif, kualitatif, dan $R \& D$. Bandung: Alfabeta. 